\title{
Synthesis and Thermal Study of Co (II), Ni (II), Cu (II) Mixed Ligand Complexes Using Histidine As Tridentate Ligand
}

\author{
Ammar J. Alabdali ${ }^{1}$, Farah M. Ibrahim ${ }^{1}$ \\ ${ }^{I}$ (Department of Chemistry, College of Science/University of Al-Nahrain, Iraq)
}

\begin{abstract}
The mixed ligand complexes of $\mathrm{Co}$ (II), $\mathrm{Ni}$ (II) and $\mathrm{Cu}$ (II) with histidine (His.) and 8hydroxyquinoline (Qui.) have been synthesized and characterized.The resulting complexes were characterized by vibrational and electronic spectral data, thermogravimetric studies, metal analysis and molar conductance measurements. The histidine acts as tridentate ligand, coordinating through the two nitrogen atoms of imidazole ring and the amino group and carboxylate oxygen whereas 8-hydroxyquinoline shows a bidentate nature and the coordination occurs through nitrogen of imine group and oxygen of phenol group. The experimental data suggest that a mononuclear octahedral structure with general formula [M(His.)(Qui.) $\mathrm{H}_{2} \mathrm{O}$ ] where $\mathrm{M}=\mathrm{Co}(\mathrm{II})$, $\mathrm{Ni}(\mathrm{II})$ and $\left[\mathrm{Cu}(\mathrm{His}).(\mathrm{Qui}.) \mathrm{H}_{2} \mathrm{O}\right] . \mathrm{H}_{2} \mathrm{O}$, thermo gravimetric studies reveal the presence of coordinated water molecules in all complexes. The molar conductance measurements reveal non-electrolytic nature of complexes.
\end{abstract}

Keywords: Histidine, 8-hydroxyquinoline, mixed ligand complexes.

\section{INTRODUCTION}

Mixed ligand complexes containing amino acid as coligand are potential biomimetic models for metalprotein interaction.${ }^{[1]}$ Research has shown significant progress in utilization of transition metal complexes as drugs to treat several human diseases like carcinomas, infection control, anti-inflammatory,diabetes and neurological disorders. ${ }^{[2]}$ The geometry, number of ligands, donor groups, nature of biniding i.e. microcoordination environment is the key to the understanding specific physiological function ${ }^{[3]}$ Histidine is a tridentate ligand that has an amino, imidazole, and carboxylate group as metal ion binding sites, but only a metal ion with an octahedral coordination sphere can form a tridentate chelate. ${ }^{[4]}$ Imidazole group plays important role in numerous bioactive compounds and pharmacological interest of the imidazole ring has already been established. It acts as proton donor / acceptor and charge transfer agent and is ligated to the metal ions in $\mathrm{B}_{12}$ coenzyme.$^{[5]}$ Ternary complexes of histidine and threonine are dominant in human serum and are important in relation to the transport of copper in blood ${ }^{[6]}$ Mixed ligand amino acid complexes are also of relevance in enzyme inhibition ${ }^{[7]}$

A pharmacological and toxicological property of amino acid complexes is another area that has drawn lot of current attention ${ }^{[8-9]}$ It has been found that metal complexes of Co (II) and $\mathrm{Ni}$ (II) with 8-hydroxyquinoline possess antibacterial and antifungal activity. ${ }^{[10]} \quad$ Some mixed ligands complexes of $\mathrm{Co}(\mathrm{II})$ and $\mathrm{Fe}$ (III) ions with malonic acid as primary and hetetrocyclic bases viz. quinoline, iso quinoline, 8-hydroxyquinoline, pryidine, 2-aminopyridine and 2-aminophenol as secondary ligands have been prepared and their antimicrobial studies have been evaluated, the complexes containing 8-hydroxyquinoline as secondary ligand were much more microbial activity than other complexes.$^{[11]}$

Mixed ligand complexes of 8-hydroxyquinoline and o-hydroxybenzylidene-1-phenyl-2, 3-dimethyl-4-amino-3pyrazolin-5-on with $\mathrm{Fe}$ (II), Co (II), Ni (II) and Cu (II) ions were synthesized, the molar conductivity of the complexes in DMF solution have non-electrolyte behavior and 8-hydroxyquinoline coordinate through the nitrogen and oxygen atoms. therefore, the complexes have tetrahedral configuration. ${ }^{[12]}$ Several mixed ligand $\mathrm{Ni}(\mathrm{II}), \mathrm{Cu}(\mathrm{II})$ and $\mathrm{Zn}$ (II) complexes of 2amino-3-hydroxypyridine(AHP) and imidazoles viz.,, imidazole (him), benzimidazole (bim), histamine(hist) and Lhistidine(his) have been synthesized and characterized, the geometry becomes tetrahedral when mixed ligand complexes are fomed with him, bim and hist for $\mathrm{Cu}(\mathrm{II})$ and $\mathrm{Zn}$ (II). All $\mathrm{Ni}$ (II) and $\mathrm{Cu}$ (II) / Zn (II) histidine mixed ligand complexes have octahedral geometry.The complexes exhibited considerable amount of antibacterial activity and $\mathrm{Cu}$ (II) complexes cleave DNA yielding scission of the sugar- phosphate backbone. ${ }^{[13]}$ Mixed ligand $\mathrm{Zr}(\mathrm{IV})$ complexes prepared with 8-hydroxyquinoline as a primary ligand and amino acids such as L-alanine/L serine/glycine as a secondary ligand. $\mathrm{Zr}(\mathrm{II})$ was used due to its high coordination number and ability to form stable complexes. These complexes were characterized and screened for their antibacterial, antifungal and cytotoxic properties.$^{[14]} \quad$ Kinetics and mechanism of thermal decomposition of o-vanilline-L-histidine complexes of some transition metal ions in which histidine acts as a tridentate ligand and an octahedral structure for the complexes has been reported ${ }^{[15]}$ Synthesis, structural, coordination and thermal stability studies of mixed ligand complexes of histidine with other ligands (adenine/guanine/ethylenediamine, diethylenetriamine or $\mathrm{N}, \mathrm{N}, \mathrm{N}^{\prime} \mathrm{N}^{\prime}, \mathrm{N}$ "'-pentamethyldiethylenetriamine, glycine or L-alanine, histamine and diethylglyoxime) have been carried out..$^{16-18]}$

In this work, we report the preparation and characterization of mixed ligand complexes with histidine as tridentate and 8-hydroxyquinoline as bidentate ligands. 


\subsection{Chemicals}

\section{EXPERIMENTAL}

Chemical reagents and starting materials were obtained from Fluka and BDH.

\subsection{Synthesis of mixed ligand complexes}

A solution of histidine was prepared by dissolving it in one equivalent of sodium hydroxide. The solution of 8-hydroxyquinoline was prepared by dissolving it in ethanol. The solution of metal ions Co (II), Ni (II) and $\mathrm{Cu}$ (II) were prepared in one equivalent of hydrochloric acid. To prepare metal complex, the two dissolved ligands were mixed with 0.1 mol. $\mathrm{L}^{-1}$ metal ion solution in 1:1:1 molar ratio at room temperature and the $\mathrm{PH}>7$ with total volume equal to $10 \mathrm{ml}$, the mixing started with addition of histidine to metal then followed by adding 8-hydroxyquinoline. The $\mathrm{PH}$ of solution was adjusted by $\mathrm{NaOH}$. The color of mixture was change and refluxed for 4 hours, the colored product was collected by filteration and washed several times with $50 \%$ ethanol-water mixture and dried in an oven at $50{ }^{\circ} \mathrm{C}$ for about one day.

\subsection{Instrumentation}

Melting points were recorded by using Gallenkamp M.F.B. $600.01 \mathrm{~F}$ of melting point apparatus . Infrared spectra were recorded using FTIR 8300 Shimadzu as $\mathrm{KBr}$ disk in the range $(4000-600) \mathrm{cm}^{-1}$.UVVisible spectra were measured using Shimadzu UV-Vis 160A Ultra-violet spectrophotometer at room temperature using silica cells of $1.0 \mathrm{~cm}$ length. The metal percent in the prepared complexes were determined using Shimadzu $680 \mathrm{cc}$-flame. Conductivity measurements of $0.001 \mathrm{M}$ ethanol solution of the complexes were measured at $25^{\circ} \mathrm{C}$ by BC3020 Professional Bench top conductivity meter Trans instruments.

\section{Results and Discussion}

The physical properties of complexes are given in table 1 in addition to the molar conductance values with $0.001 \mathrm{M}$ in ethanol as a solvent at room temperature $25^{\circ} \mathrm{C}$ which indicating non electrolyte behavior.

Table 1: Physical data of mixed ligand complexes

\begin{tabular}{|c|c|c|c|c|c|}
\hline Compound & $\begin{array}{l}\text { Formula and } \\
\text { name }\end{array}$ & $\begin{array}{l}\text { Color and } \\
\text { m.p. }\end{array}$ & $\begin{array}{l}\text { Metal analysis } \\
\text { Found (Calc.) }\end{array}$ & $\begin{array}{l}\text { Molar } \\
\text { Conductivity } \\
\mu \mathrm{s}\end{array}$ & $\begin{array}{l}\text { Suggested } \\
\text { Structure }\end{array}$ \\
\hline HQCo & $\begin{array}{l}{[\mathrm{Co}(\text { his. })(\text { quin. })]} \\
\text { Histidinatoquinolino } \\
\text { cobalt(II) }\end{array}$ & $\begin{array}{l}\text { Green } \\
200{ }^{\circ} \mathrm{C}\end{array}$ & $15.5(15.6)$ & 3.21 & Octahedral \\
\hline HQNi & $\begin{array}{l}\text { [Ni(his.)(quin.)] } \\
\text { Histidinatoquinolino } \\
\text { nickelt(II) }\end{array}$ & $\begin{array}{l}\text { Light green } \\
280^{\circ} \mathrm{C}\end{array}$ & $15.4(15.5)$ & 17.63 & Octahedral \\
\hline $\mathrm{HQCu}$ & $\begin{array}{l}{[\mathrm{Cu} \text { (his.)(quin.) }]} \\
\text { Histidinatoquinolino } \\
\text { copper(II) }\end{array}$ & $\begin{array}{l}\text { Dark green } \\
290^{\circ} \mathrm{C}\end{array}$ & $14.9(15.8)$ & 20.0 & Octahedral \\
\hline
\end{tabular}

\subsection{Ultraviolet-visible spectroscopy}

The octahedral Co (II) is known to has the following three spin allowed transition $\left(v_{1}\right){ }^{4} \mathrm{~T}_{1} \mathrm{~g}(\mathrm{~F}) \rightarrow{ }^{4} \mathrm{~T}_{2} \mathrm{~g}(\mathrm{~F})$, $\left(v_{2}\right){ }^{4} \mathrm{~T}_{1} \mathrm{~g}(\mathrm{~F}) \rightarrow{ }^{4} \mathrm{~A}_{2} \mathrm{~g}(\mathrm{~F})$ and $\left(\mathrm{v}_{3}\right){ }^{4} \mathrm{~T}_{1} \mathrm{~g}(\mathrm{~F}) \rightarrow{ }^{4} \mathrm{~T}_{2} \mathrm{~g}(\mathrm{P})$ out of these, the first transition $\left(\mathrm{v}_{1}\right)$ usually occurs lower frequencies and is expected to appear beyond $1000 \mathrm{~nm}$ in the near infrared region. The position of $\left(v_{2}\right)$ transition in Co (II) complex, however be ambiguous and is rather difficult to locate with certainty sometimes it appears as a shoulder on either side of the main absorption band ( $v_{3}$ transition) or in some cases it may not be observed at all . ${ }^{[19]}$ Thus in the present study of cobalt (II) complex, the transition obtained at $953 \mathrm{~nm}$ can be assigned as $v_{1}$ transition. The main absorption band observed at $752 \mathrm{~nm}$ can be assigned as $v_{3}$ transition. The position of $v_{2}$ transition is not clear; other bands observed at 238,426 can be regarded as ligand field and charge transfer bands, respectively.

The band at $341 \mathrm{~nm}$ is typical ligand based transition. $\mathrm{Ni}(\mathrm{II})$ complex shows three bands with $\lambda$ max value in the range 410, 740- $767 \mathrm{~nm}$ and around $916 \mathrm{~nm}$, these bands assigned to the respective d-d transitions, ${ }^{3} \mathrm{~A}_{2} \mathrm{~g}(\mathrm{~F}) \rightarrow{ }^{3} \mathrm{~T}_{1} \mathrm{~g}(\mathrm{P})$, ${ }^{3} \mathrm{~A}_{2} \mathrm{~g}(\mathrm{~F}) \rightarrow{ }^{3} \mathrm{~T}_{1} \mathrm{~g}(\mathrm{~F}),{ }^{3} \mathrm{~A}_{2} \mathrm{~g}(\mathrm{~F}) \rightarrow{ }^{3} \mathrm{~T}_{2} \mathrm{~g}(\mathrm{~F})$ with $\mathrm{Ni}(\mathrm{II})$ ion the octahedral ligand field . ${ }^{[5]}$

The electronic spectrum of $\mathrm{Cu}$ (II) shows d-d transition at $680 \mathrm{~nm}\left\{{ }^{2} \mathrm{Eg} \rightarrow{ }^{2} \mathrm{~T}_{2} \mathrm{~g}\right.$ (F) transition $\}$ is more consistent with octahedral geometry..$^{[5]}$

\subsection{Infrared spectra of complexes}

The characteristic vibrations modes of mixed ligand complexes are described in table 2. IR spectra of HQCo (m.p $\left.200{ }^{\circ} \mathrm{C}\right)$, HQNi (m.p $\left.280{ }^{\circ} \mathrm{C}\right)$ and $\mathrm{HQCu}\left(290{ }^{\circ} \mathrm{C}\right)$ complexes show a broad band in the range of $3450-3435 \mathrm{~cm}^{-1}$ followed by another band in the range $800-817 \mathrm{~cm}^{-1}$, which is due to characteristic of $v \mathrm{OH}$ of coordinated water. An important feature of infrared spectra of the metal complexes with Qui. is the absence of $\mathrm{O}-\mathrm{H}$ stretching vibration of the free phenol group $\mathrm{O}-\mathrm{H}$ appear about $3150 \mathrm{~cm}^{-1}$ region. A presence of $v(\mathrm{C}-\mathrm{O})$ band at $1215 \mathrm{~cm}^{-1}$ in Qui. spectrum, shifting to the higher frequencies between $7-19 \mathrm{~cm}^{-1}$ in the spectrum of 
mixed ligand complexes, indicating the coordination of phenolic oxygen to metal ion. ${ }^{[10]}$ The $v(\mathrm{C} \square \mathrm{N})$ band observed at $1575 \mathrm{~cm}^{-1}$ in the spectrum of Qui. ligand, this band reduced in intensity with shifting to lower wave number $1537 \mathrm{~cm}^{-1}$ in the spectra of complexes, this indicates the coordination through nitrogen donor of Qui. with the metal.$^{[13]}$

In amino acid $v \mathrm{NH}_{3}{ }^{+}$appears in 3130-3030 $\mathrm{cm}^{-1}$ region.$^{[20]}$ In the spectrum of His. it appears at 3082 $\mathrm{cm}^{-1}$ but overlaps with other vibrations such as $v \mathrm{NH}$ (imidazole group) and $v \mathrm{CH}$ (heterocyclic $+v \mathrm{CH}_{2}$ group $\square$ $3016 \mathrm{~cm}^{-1}$ ). Theoretically $v \mathrm{NH}_{3}{ }^{+}$should vanish on coordination. In metal complexes, however, some broad band appears at $\square 3300 \mathrm{~cm}^{-1}$, which must be arising from other vibrations appearing in this region. ${ }^{[21]}$ In His. spectrum in plane deformation $\delta\left(\mathrm{NH}_{3}{ }^{+}\right)$appears at $1633 \mathrm{~cm}^{-1}$ which vanishs in metal complexes. The $v_{\text {asym }}$ (COO) band of His. observed at $1633 \mathrm{~cm}^{-1}$ is shifted to lower wave number $1600-1625 \mathrm{~cm}^{-1}$ and the $v_{\text {sym }}$ $\left(\mathrm{COO}^{-}\right)$mode observed $1413 \mathrm{~cm}^{-1}$ in the spectrum of His. is found to be shifted to lower wave number 1377$1380 \mathrm{~cm}^{-1}$ in the spectra of complexes indicating the coordination of carboxylic acid group via oxygen with metal. The magnitude of separation between these two vibrations $\left(>200 \mathrm{~cm}^{-1}\right)$ suggests that the coordination of carboxylate group is in unidentate fashion.$^{[10]}$ The imidazole exhibit a strong $\mathrm{C} \square \mathrm{N}$ ring band in the region $1581-1577 \mathrm{~cm}^{-1}$ which is shifted to $1535 \mathrm{~cm}^{-1}$ in all complexes. This lower value of imidazole $v \mathrm{C} \square$ Nindicates that imidazole nitrogen in coordination with the metal ion in all the complexes. ${ }^{[5]}$ The infrared of prepared complexes have shown weak bands in the range of (430-474) $\mathrm{cm}^{-1}$ and (524- 576) $\mathrm{cm}^{-1}$ which was attributed to the $v(\mathrm{M}-\mathrm{O})$ and $v(\mathrm{M}-\mathrm{N})$ respectively. ${ }^{[4,13]}$

Table 2: The characteristic bands of infrared spectra of the mixed ligand complexes

\begin{tabular}{|c|c|c|c|c|c|c|c|}
\hline Compound & $\begin{array}{l}v(\mathrm{O}-\mathrm{H}) \\
\text { phenol }\end{array}$ & $\begin{array}{l}p(\mathrm{C}=\mathrm{N}) \\
\text { imine }\end{array}$ & $\begin{array}{l}v(\mathrm{C}-\mathrm{O}) \\
\text { phenol }\end{array}$ & $\begin{array}{l}v_{\text {asym }}\left(\mathrm{COO}^{-}\right) \\
v_{\text {sym }}\left(\mathrm{COO}^{-}\right)\end{array}$ & $\begin{array}{l}v(\mathrm{C}=\mathrm{N}) \\
\text { imidazole }\end{array}$ & $v(\mathrm{M}-\mathrm{N})$ & $v(\mathrm{M}-\mathrm{O})$ \\
\hline Qui & 3150 & 1575 & 1215 & - & - & - & - \\
\hline His & - & - & - & $\begin{array}{l}1633 \\
1413\end{array}$ & 1581 & - & - \\
\hline HQCo & - & 1537 & 1222 & $\begin{array}{l}1625 \\
1377 \\
\end{array}$ & 1535 & 528 & 440 \\
\hline HQNi & - & 1537 & 1234 & $\begin{array}{l}1600 \\
1379 \\
\end{array}$ & 1535 & 576 & 474 \\
\hline $\mathrm{HQCu}$ & - & 1537 & 1230 & $\begin{array}{l}1600 \\
1380 \\
\end{array}$ & 1535 & 524 & 430 \\
\hline
\end{tabular}

\subsection{Thermal studies}

The TG and DTA studies of complexes have been recorded in the helium gas at the constant heating rate of $20{ }^{\circ} \mathrm{C} / \mathrm{min}$. The complexes show gradual loss in weight due to decomposition by fragmentation with increasing temperature. Thermogravimetric curve of $\mathrm{HQCo}, \mathrm{HQNi}$ and $\mathrm{HQCu}$ complexes show the presence of coordinated water and $\mathrm{HQCu}$ complex also show water molecule in outer of the coordination sphere.

Thermogram of these complexes shows the loss in weight corresponding to water molecules with moiety of histidine, followed by weight loss of 8-hydroxyquinoline as well as $\mathrm{CO}_{2}$ moieties present in the complexes. ${ }^{[10,5]}$ thermolysis data for complexes are given in table 3 .

Table3: Thermolysis data for HQCo, HQNi and HQCu complexes.

\begin{tabular}{|c|c|c|c|c|c|c|}
\hline \multirow[t]{2}{*}{ NO. } & \multirow[t]{2}{*}{ Complex } & \multirow{2}{*}{$\begin{array}{l}\text { Temperature } \\
\text { range, }{ }^{\circ} \mathrm{C}\end{array}$} & \multicolumn{2}{|c|}{$\%$ Weight loss } & \multirow[t]{2}{*}{ Decomposition product } & \multirow{2}{*}{$\begin{array}{l}\text { Liberate } \\
\text { part }\end{array}$} \\
\hline & & & Found & Calcd. & & \\
\hline \multirow{4}{*}{1.} & \multirow[t]{4}{*}[\mathrm{CoC}_{15}\mathrm{H}_{16}\mathrm{N}_{4}\mathrm{O}_{4}]{} & $30-100$ & 17.2 & 18.5 & {$\left[\mathrm{CoC}_{12} \mathrm{H}_{10} \mathrm{~N}_{2} \mathrm{O}_{4}\right]$} & $\mathrm{C}_{3} \mathrm{H}_{6} \mathrm{~N}_{2}$ \\
\hline & & $140-240$ & 5.5 & 7.9 & {$\left[\mathrm{CoC}_{11} \mathrm{H}_{8} \mathrm{~N}_{2} \mathrm{O}_{3}\right]$} & $\mathrm{H}_{2} \mathrm{O}, \mathrm{C}$ \\
\hline & & $300-400$ & 31.7 & 34.2 & {$\left[\mathrm{CoC}_{2} \mathrm{H}_{2} \mathrm{NO}_{3}\right]$} & $\mathrm{C}_{9} \mathrm{H}_{6} \mathrm{~N}$ \\
\hline & & $600-730$ & 12.4 & 14.8 & {$\left[\mathrm{CoONH}_{2}\right]$} & $\mathrm{CO}_{2}, \mathrm{C}$ \\
\hline \multirow[t]{4}{*}{2.} & \multirow[t]{4}{*}[\mathrm{NiC}_{15}\mathrm{H}_{16}\mathrm{N}_{4}\mathrm{O}_{4}]{} & $110-190$ & 22.7 & 23.2 & {$\left[\mathrm{NiC}_{12} \mathrm{H}_{8} \mathrm{~N}_{2} \mathrm{O}_{3}\right]$} & $\begin{array}{l}\mathrm{C}_{3} \mathrm{H}_{6} \mathrm{~N}_{2} \\
\mathrm{H}_{2} \mathrm{O}\end{array}$ \\
\hline & & $230-300$ & 6.2 & 6.3 & {$\left[\mathrm{NiC}_{10} \mathrm{H}_{8} \mathrm{~N}_{2} \mathrm{O}_{3}\right]$} & $\mathrm{C}$ \\
\hline & & $315-500$ & 33.1 & 34.2 & {$\left[\mathrm{NiCH}_{2} \mathrm{NO}_{3}\right]$} & $\mathrm{C}_{9} \mathrm{H}_{6} \mathrm{~N}$ \\
\hline & & $530-700$ & 13.8 & 15.8 & {$[\mathrm{NiO}]$} & $\mathrm{CO}_{2} \mathrm{NH}_{2}$ \\
\hline \multirow[t]{4}{*}{3.} & \multirow[t]{4}{*}[\mathrm{CuC}_{15}\mathrm{H}_{18}\mathrm{N}_{4}\mathrm{O}_{5}]{} & $100-150$ & 23.2 & 24.7 & {$\left[\mathrm{CuC}_{11} \mathrm{H}_{13} \mathrm{~N}_{2} \mathrm{O}_{4}\right]$} & $\begin{array}{l}\mathrm{H}_{2} \mathrm{O} \\
\mathrm{C}_{4} \mathrm{H}_{5} \mathrm{~N}_{2}\end{array}$ \\
\hline & & $150-280$ & 10.5 & 11.7 & {$\left[\mathrm{CuC}_{10} \mathrm{H}_{8} \mathrm{NO}_{3}\right]$} & $\begin{array}{l}\mathrm{H}_{2} \mathrm{O} \\
\mathrm{CH}_{3} \mathrm{~N}\end{array}$ \\
\hline & & $280-400$ & 10.5 & 10.9 & {$\left[\mathrm{CuC}_{9} \mathrm{H}_{8} \mathrm{NO}\right]$} & $\mathrm{CO}_{2}$ \\
\hline & & $400-800$ & 17.5 & 16.7 & {$\left[\mathrm{CuC}_{5} \mathrm{H}_{3} \mathrm{~N}\right]$} & $\mathrm{C}_{4} \mathrm{H}_{3} \mathrm{O}$ \\
\hline
\end{tabular}

\section{Conclusion}

The evidences obtained from the above studies suggest an octahedral structure for HQCo, HQNi and $\mathrm{HQCu}$ with tridentate histidine ligand and bidentate 8-hydroxyquinoline ligand. The molar conductivity of 
complexes has non- electrolytic nature of all complexes. Thermal analysis confirms the presence of a coordinated water molecule in all prepared complexes and water molecule out of the coordination sphere of $\mathrm{HQCu}$ complex.

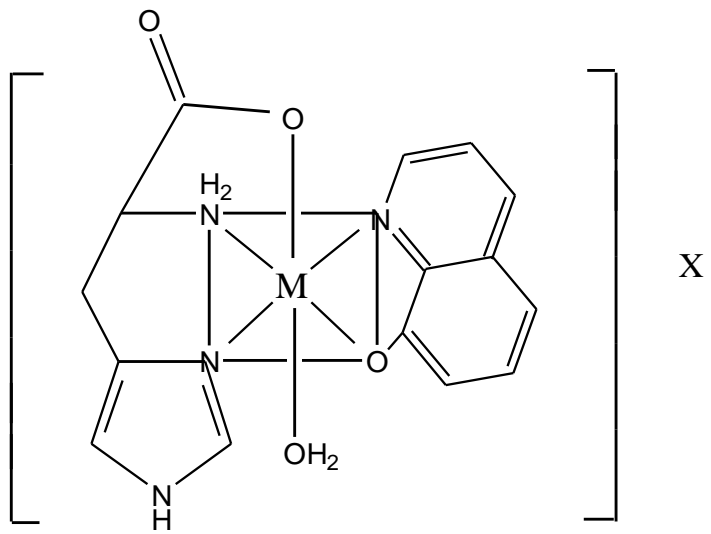

$\mathrm{M}=\mathrm{Co}(\mathrm{II}), \mathrm{Ni}(\mathrm{II})$ cobalt and nickel complexes

$\mathrm{M}=\mathrm{Cu}(\mathrm{II}), \mathrm{X}=\mathrm{H}_{2} \mathrm{O}$ copper complex

\section{REFERENCES}

[1] R.Carballo , A.Castineiras, B.Covelo , E.G.Martinez and E.M.V. Lopez, Solid state coordination chemistry of mononuclear mixed ligand complexes of $\mathrm{Ni}(\mathrm{II}), \mathrm{Cu}(\mathrm{II})$ and $\mathrm{Zn}$ (II) with a-hydroxycarboxylic acids and imidazole Polyhedron ,23,2004,1518.

[2] S.Rafique, M. Idrees, A. Nasim,H. Akbar and A. Athar, ,Biotechnol. Mol. Biol. Rev. , 5,2010 ,38.

[3] D.L.Stone, D.K.Smith and A.C.Whitwood, Copper aminoacid complexes towards encapsulated metal centres., Polyhedron ,23,2004,1709.

[4] H.Sigel and D.B.McCormick, Structure of the copper(II)-L-histidine1:2 complex in solution,J.Am.Chem.Soc.,93(8) ,1971, 2041.

[5] M.A.Neelakantan,M. Sundaram and N.M. Sivasankaran, Synthesis,spectral and thermal studies of some transition metal mixed ligand complexes: Modeling of equilibrium composition and biological activity, Spectrochimica Acta Part A: Molecular and Biomolecular Spectroscopy, 79,2011,1693.

[6] C.D.Vulpe and S. Packman, Cellular copper transport. Annu.Rev.Nutr,15, 1995,293.

[7] E. Farkas ,E.A. Enyedy ,G.Micera and E.Garribbs, Coordination modes of hydroxamic acids in copper (II), nickel (II) and Zn (II) mixed ligand complexes in aqueous solution, Polyhedron. ,19,2000,1727.

[8] A.Dondoni ,A. Massi, E. Minghini and V. Berolasi Multicomponent Hantzsch cyclocondensation as a route to highly functionlized 2- and 4-dihydropyridylalanines, 2-and 4-pyridyl alanines and their N-oxides: preparation via a polymer assisted solution phase approach.,Tetrahedron,60,2004,2311.

[9] C.Janiaj, Acritical account on -stacking in metal complexes with aromatic nitrogen containing ligands ,J.Chem.Soc.Dalton Trans.,3885,2000

[10] S.P.Sunil ,A.Th. Ganesh and M.Sh. manzoor, Characterization and antibacterial studies on some mixed ligand thorium complexes with N-and O-donor ligands, Acta poloniae pharmaceutica-Drug Research,, 68(6),2011,881-887.

[11] Md.Y.Reza, Md.B. Hossain, M.S. Islam and Sh. Alam Sh., Antimicrobil studies of mixed ligand transition metal complexes of maleic acid and hetrocyclic bases, Pakistan Journal of Biological Sciences,6(15),2003.1314-1316

[12] Sh.A.Shaker,Y. Farina and A.A. Salleh, Synthesis andcharacterization of mixed ligand complexes of 8-hydroxyquinoline and ohydroxybenzylidene-1-phenyl-1,2.3-dimethyl-4-amino-3-pyrazolin-5-on with Fe(II), Co(II), Ni(II) and Cu(II) ions, European Journal of Scientific Research 33(4),2009,702-709.

[13] Y.S.Malghe, R.C. Prabhu and R.W. Raut, Synthesis,characterization and biological activities of mixed ligand Zr(IV) complexes Acta Poloniae Pharmaceutica- Druge Research ,66(1),2009,45-50.

[14] B.Saleema and G. Parameswaran, Kinetics and mechanism of the thermal decomposition of o-vanilline-L-histidine complexes of transition metal ions. Asian J.Chem.,15,2003,1491-1499.

[15] N.P.Singh , M.N.Srivastava and G. Kumar, Synthesis and structural studies of some mixed ligand transition metal complexes of histidine and adenine or guanine ,Orient J. Chem. ,16,2000, 223-227.

[16] B.Kurzak, A. Kameeka, K. Bogusz and J.Jezierska, Stabilities and coordination models of histidine copper (II) mixed ligand with ethylenediamine, diethylenetriamine or N,N,N'N",N"'-pentamethyldiethylenetriaminein aquous solution.Polyhedron., 27,2008, 2952 $-2958$.

[17] A.Adkhis, O. Benali-Baitich, M.A.Khan and G. Bouet, Synthesis,characterization and thermal behavior of mixed ligand complexes of cobalt (II) with dimethylglyoxime and some amino acids, Synth. React.Inorg.Met-Org.Chem.,30,2000,1849-1858

[18] Y.Altun and F.Koseoglu, Sability of copper (II), Nickel(II) and Zinc (II) binary and ternary complexes of histidine,histamine and glycine in aqueous solution. J.Sol.Chem.,34, 2005,213-231 .

[19] F.A.Cotton, G. Wilkinson, C.A. Murilo and M. Bochmann ,"Advanced Inorganic Chemistry"( $6^{\text {th }}$ ed., John Wiley and Son: New York,1999)

[20] K.Nakamoto " Infrared of inorganic and coordination compounds",( $6^{\text {th }}$ ed., John Wiley:New York,1997)

[21] G.Kumar, Preparation,coordination and structure of mixed ligand cobalt(II) complexes of histidine and hippuric acid ,Chemistry,18(2),2009, 130 . 